\title{
Intrahepatic Bile Duct Cancer pTX TNM
} Finding v7

National Cancer Institute

\section{Source}

National Cancer Institute. Intrahepatic Bile Duct Cancer pTX TNM Finding v7. NCI

Thesaurus. Code C90185.

Intrahepatic bile duct cancer in which the primary tumor cannot be assessed. (from AJCC 7th Ed.) 